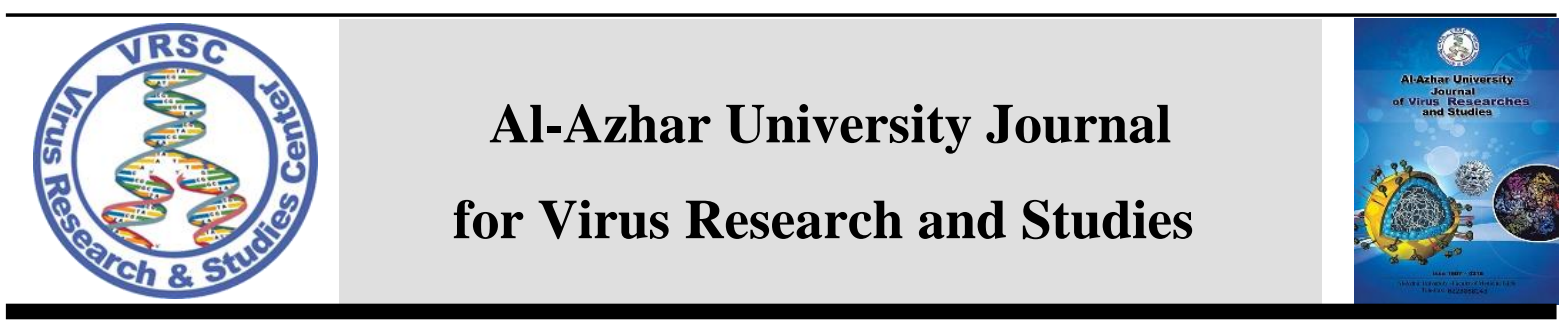

\title{
Assessment of Antibacterial, Antifungal, Antioxidant and Antiviral Activities of Black pepper Aqueous Seed Extract
}

\author{
Ghadir E. Daigham ${ }^{1}$ and Amira Y. Mahfouz ${ }^{1^{*}}$ \\ ${ }^{1}$ Botany and Microbiology Department, Faculty of Science, Al-Azhar University (Girls \\ Branch), Cairo, Egypt.
}

*E-mail: amira.mohamed@azhar.edu.eg

\begin{abstract}
Traditional plant - based compounds are seeking more attention in pharmaceutical aspects to treat untreatable diseases because they have no side effect, easy recovery in great amount and a high degree of activity. Spices are extensively used to improve the taste and flavor of food, acquire a broad range of medicinal properties and some of them are known to be antioxidants. The antibacterial activity of aqueous seeds extract of Piper nigrum L. was evaluated against some pathogenic bacteria. The maximum inhibition zone was accounted against Gram negative bacteria Klebsiella oxytoca $(21 \pm 0.11 \mathrm{~mm})$ and minimum inhibition zone was exhibited against Gram positive bacteria Enterococcus faecalis $(7 \pm 0.05 \mathrm{~mm})$ while has no activity against Pseudomonas aeruginosa. Moreover, the aqueous seeds extract completely inhibits Penicillium citrinum growth at $500 \mu \mathrm{l}$ by using food-poisoning technique and also showed some activity in controlling the mycelial growth of Aspergillus niger and Aspergillus flavus. Aqueous seeds extract of Piper nigrum L. was evaluated against Herpes simplex virus (HSV1) and Coxsackie virus (COXB4) and the results showed that Piper nigrum exert (57.26 and $13.41 \%$ ) inhibition of plaque of HSV1 and COXB4 respectively. Moreover, the maximum nontoxic concentration (MNTC) for black pepper aqueous seed extract was $2500 \mu \mathrm{g} / \mathrm{ml}$. The extract shows antioxidant activities with IC50 $=155 \mu \mathrm{g} / \mathrm{ml}$ and total phenolic content of (194.05 mg GA/g extract). These results suggest that aqueous seeds extract of Piper nigrum have significant anti-viral, antibacterial, antifungal and antioxidant activity signifying its usage as accepted antimicrobial representative.
\end{abstract}

Keywords: Piper nigrum L., Antibacterial, Antioxidant, HSV1 and COXB4.

\section{Introduction}

For many years, profitable antimicrobial drugs are used for the management of transmittable diseases. However, recently; the random apply of those antibiotics leads to the increase of many resistances and undesirable side effects. For that reason, more natural antimicrobial substances from plants are desired. An over-sized number of herbs possess antimicrobial activity [1], [2] and a few active components of them became a possible source of new antiinfective agents [3], [4]. Herbs and spices are applied widely because of their sensory characters, distinctive pharmacological roles, and antimicrobial potency [5], [6]. Piper nigrum L. is a type of famous spice 
owing to its attractive aroma, typical strong and tingling impression [7]. Many authors have declared that terpenoids, the major compounds from black pepper essential oil, have the potential antibacterial activity [8]. Hydrophobicity is an important feature of essential oil components which make them able to panel through the lipid layer of bacterial cell membrane, disrupting the cellular structures, causing lyses and leakage of intracellular components [9], [10]. Pepper essential oil has a very important responsibility in the fabrication of perfumery and confectionery products. Volatile oils of spice and extracts of aromatic plant were reported to possess sturdy antioxidant [11] and antimicrobial activities [12], [13]. Antiviral and cytotoxic activities of seed extracts of Piper nigrum on human cell lines were also reported [14]. Furthermore, $P$. nigrum is recorded to be gifted with health benefits and diseasepreventing actions, such as antiinflammatory, antiviral, immune and bioavailability enhancing qualities [15]. Antioxidants conflict free radicals and oxidants in the body, by this means enhancing general health. Despite the fact that many oxidants are caused by environmental factors viz; pollution, smoking and others, a quantity of oxidants have resulted directly from ordinary reactions inside the body, as aerobic respiration and inflammation. Doesn't matter what the cause, the body needs antioxidants to wipe out these harmful free radicals. Various plant extracts including black pepper, afford the body with these antioxidants to fight free radicals and repair the damage they cause [16], [17]. Therefore, this study aims to estimate the antibacterial, antifungal, antioxidant and antiviral activities of black pepper aqueous seeds extract.

\section{MATERIALS AND METHODS}

\subsection{Collection of plant material and carrying out the extraction method:}

This Seeds of black pepper were obtained from markets, Cairo, Egypt. Twenty-five grams of black pepper seeds were grinded using a mortar in order to obtain fine powdered form. The obtained powdered sample was hermetically conserved in polythene bag till the time of the extraction. Ten grams of powdered Piper nigrum were added to $100 \mathrm{ml}$ of hot distilled water intended for $6 \mathrm{hrs}$. After that, filtration of the extract was done by Whatman filter paper No (1) and then was vacuum evaporated at low pressure in a rotary evaporator to obtain a dried crude extract. Stock solutions were made in DMSO to obtain the required extract concentration $(10 \mathrm{mg} / \mathrm{ml})$ and then stored at refrigerator for further use.

\subsection{Evaluations of antibacterial activity of black pepper aqueous seed extract using paper disk diffusion method:}

Bacterial Cultures: Bacillus subtilis, Enterococcus faecalis, Escherichia coli, Klebsiella oxytoca, Staphylococcus aureus, Proteus vulgaris and Pseudomonas aeruginosa. Bacterial suspension of $24 \mathrm{hrs}$. culture of each pathogen was prepared and inoculated on nutrient agar plates. $20 \mu \mathrm{l}$ of black pepper aqueous seed extract $(100 \mu \mathrm{g} / \mathrm{ml})$ were loaded on a sterile disc measuring $6 \mathrm{~mm}$ (Whatman filter paper No. 1 ), then the disc was placed onto the agar plates which left to stand for $30 \mathrm{~min}$ and finally incubated at $37{ }^{\circ} \mathrm{C}$ for $18-24 \mathrm{hrs}$. By ending the incubation period, the inhibition zones were deliberated and recorded as $\mathrm{mm}$. Ciprofloxacin $(20 \mu \mathrm{g} / \mathrm{ml})$ and distilled water were used as positive and negative control respectively. 


\subsection{Evaluation of antifungal activity of black pepper by food- poisoning technique:}

Each The antifungal activity of black pepper aqueous seed extract against (Aspergillus flavus, Aspergillus niger, Fusarium oxisporum, and Penicillium citrinum) was evaluated by food-poisoning techniques according to the method described by [18]. The fungal strains were multiplied on potato dextrose agar for 7 days at 280C. Petri plates containing PDA supplemented with black pepper aqueous extract at three concentrations (100, 250 and $500 \mu \mathrm{l})$ were inoculated with 7 days' culture of selected fungi $(5 \mathrm{~mm}$ diameter disc). PDA plate devoid of extract is used as control. Incubation was done at $280 \mathrm{C}$ for 7 days. The toxicity was deliberate in terms of percentage mycelial inhibition and the following equation was used for its calculation:

Percentage mycelial inhibition $=[(\mathrm{d}$ control-d treatment $) / \mathbf{d}$ control $] \times \mathbf{1 0 0}$. Incubation was done at $28^{\circ} \mathrm{C}$ for 7 days.

\subsection{Determination of antiviral activity of black pepper aqueous seed extract:}

Preparation This experiment was carried out at Science Way for Scientific Research and Consultations, Cairo, Egypt. (All viruses were obtained from Microbiology Department, Faculty of Medicine Al-Azhar University (Girls Branch).

\subsubsection{Determination of samples cytotoxicity on Vero cell:}

Various concentrations of the sample under investigation were prepared. The medium used for growth was decanted from 96 well microtiter plates later than the confluent sheet of Vero cell was produced; Washing of the cell monolayer was done twice using wash media. Double-fold dilutions of the tested samples were made in DMEM. 0.1 $\mathrm{ml}$ of each one dilution was tested in different wells leaving 3 wells as control, receiving only maintenance medium. The plate was incubated at $370 \mathrm{O}$ for 48 hours and examined regularly. Any physical signs of cell toxicity like loss of the monolayer, rounding, shrinkage, or cell granulation should be detected. About $(5 \mathrm{mg} / \mathrm{ml}$ in PBS) of MTT solution was prepared (BIO BASIC CANADA INC). Each well was filled with $20 \mu \mathrm{l}$ MTT solution., to the MTT was thoroughly mix into the media by Shaking at 150rpm for 5 minutes. Incubation was run at $\left(37^{\circ} \mathrm{C}, 5 \%\right.$ $\mathrm{CO}_{2}$ ) for 4 hours. The plate was dried on paper towels to get rid of remains. The metabolic product (Formazan) was resuspeneded in $200 \mu \mathrm{l}$ DMSO, shaked at $150 \mathrm{rpm}$ for 5 minutes, to allow mixing the formazan with the solvent. O.D. was recorded at $560 \mathrm{~nm}$ and subtracts background at $620 \mathrm{~nm}$. O.D. must be directly interrelated with quantity of cell. The maximum non-toxic concentration [MNTC] of each extract was also estimated.

\subsubsection{Antiviral assay (MTT Assay Protocol).}

After Ten thousand $(10,000)$ cells were plate in $200 \mu 1$ media per well in a 96 well plate. 3 empty wells were serving as blank controls. Incubation was carried out at $\left(37^{\circ} \mathrm{C}, 5 \% \mathrm{CO}_{2}\right)$ all night to allow attaching the cells to the wells. Incubation of equal volume $(1: 1 \mathrm{v} / \mathrm{v})$ of non-lethal dilution of tested sample and the viral suspension for one hour was carried out. $100 \mu \mathrm{l}$ from viral/ sample suspension was added, placed on a shaking table at $150 \mathrm{rpm}$ for 5 minutes then incubation at $\left(37^{\mathrm{O}} \mathrm{C}, 5 \% \mathrm{CO}_{2}\right)$ for one day was done to allow the virus to take effect. $2 \mathrm{ml}$ or more of MTT solution per 96 well plate at $5 \mathrm{mg} / \mathrm{ml}$ in PBS was added and shaked at 150rpm for 5 minutes, to allow mixing the MTT with the media and then incubated for $1-5$ hours at $\left(37^{\circ} \mathrm{C}, 5 \% \mathrm{CO}_{2}\right)$. The plate was dried on paper towels to get rid of remains. The metabolic product 
(Formazan) was resuspeneded in $200 \mu 1$ DMSO, shaked at $150 \mathrm{rpm}$ for 5 minutes, to allow mixing the formazan with the solvent. O.D. was recorded at $560 \mathrm{~nm}$ and subtracts background at $620 \mathrm{~nm}$. O.D. must be directly interrelated with quantity of cell. The maximum non-toxic concentration [MNTC] of each extract was also estimated.

\subsection{Determination of antioxidant activity of black pepper aqueous seed extract:}

The antioxidant activity of black pepper aqueous seed extract was estimated in accordance with [19]. Briefly, $0.1 \mathrm{ml}$ of black pepper aqueous seed extract was added to $0.9 \mathrm{ml}$ distilled water in a test tube to which $3.9 \mathrm{ml}$ of methanolic DPPH solution was added. The tube was allowed to rest in the dark for 30 minutes. The absorbance was deliberated at $515 \mathrm{~nm}$ against a blank of distilled water. This experiment was conceded at the Central Water Quality Laboratory of Greater Cairo Water Company, Cairo, Egypt using the DPPH free radical scavenging system.

\subsection{Determination of total phenolic contents (TPC):}

The total phenolic contents of black pepper aqueous seed extract were estimated according to the method described by [20]. $500 \mu 1$ of extracts of black pepper aqueous seed extract were added to $1000 \mu 1$ of $1: 10$ Folin-Ciocalteu's reagent. The mixture was incubated at room temperature for 5 minutes then $900 \mu \mathrm{l}$ of sodium carbonate solution (7.5\%) was added and again incubated at room temperature for 60 minutes. The O.D was determined at 765 $\mathrm{nm}$ via UV-VIS spectrophotometer and (TPC) of the sample was expressed as gallic acid equivalents $\mathrm{mg} / \mathrm{g}$ of the extracts.

\subsection{Statistical Analysis:}

The Data were analyzed by one-way ANOVA at $p<0.05$ and offered as mean \pm SD using IBM Corp (Released 2016. IBM
SPSS Statistics for Windows, Version 24.0. Armonk, NY: IBM Corp).

\section{Experimental Results}

\subsection{Antibacterial activity}

The antibacterial activity of the black pepper aqueous seed extract was assessed against Gram positive bacteria (Bacillus subtilis, Enterococcus faecalis and Staphylococcus aureus) and Gram negative bacteria (Escherichia coli, Klebsiella oxytoca and Proteus vulgaris and Pseudomonas aeruginosa) table (1) and figure (1). The results indicated that the black pepper aqueous seed extract exhibited potent antibacterial activity against Gram negative bacteria Klebsiella oxytoca with inhibition zone of $(21 \pm 0.02$ $\mathrm{mm})$ compared with positive control ciprofloxacin $(34 \pm 0.11) \mathrm{mm}$. Moreover, the smallest inhibition zone was accounted against Gram positive bacteria Enterococcus faecalis $(7 \pm 0.05 \mathrm{~mm})$ while it has no activity against Pseudomonas aeruginosa.

Table 1. Inhibition zone $(\mathrm{mm})$ of black pepper aqueous seed extract against various pathogenic bacteria:

\begin{tabular}{|c|c|}
\hline Bacterial strain & $\begin{array}{c}\text { Mean diameter } \\
\text { of inhibition } \\
\text { zone (mm) }\end{array}$ \\
\hline Bacillus subtilis & $12 \pm 0.10$ \\
\hline $\begin{array}{c}\text { Enterococcus } \\
\text { faecalis }\end{array}$ & $7 \pm 0.05$ \\
\hline $\begin{array}{c}\text { Staphylococcus } \\
\text { aureus }\end{array}$ & $13 \pm 0.26$ \\
\hline Escherichia coli & $11 \pm 0.20$ \\
\hline Klebsiella oxytoca & $21 \pm 0.11$ \\
\hline Proteus vulgaris & $9 \pm 0.11$ \\
\hline $\begin{array}{c}\text { Pseudomonas } \\
\text { aeruginosa }\end{array}$ & $0 \pm 00$ \\
\hline
\end{tabular}

\subsection{Antifungal activity:}

Concerning the antifungal activity of black pepper aqueous extract using food- 
poisoning technique, it was clear from the obtained results recorded in table (2) that the aqueous seed extract of black pepper completely inhibit growth of Penicillium citrinum causing (100\% inhibition) at 500 $\mu l$ concentration. It is also found to be more effective in retarding of Aspergillus niger
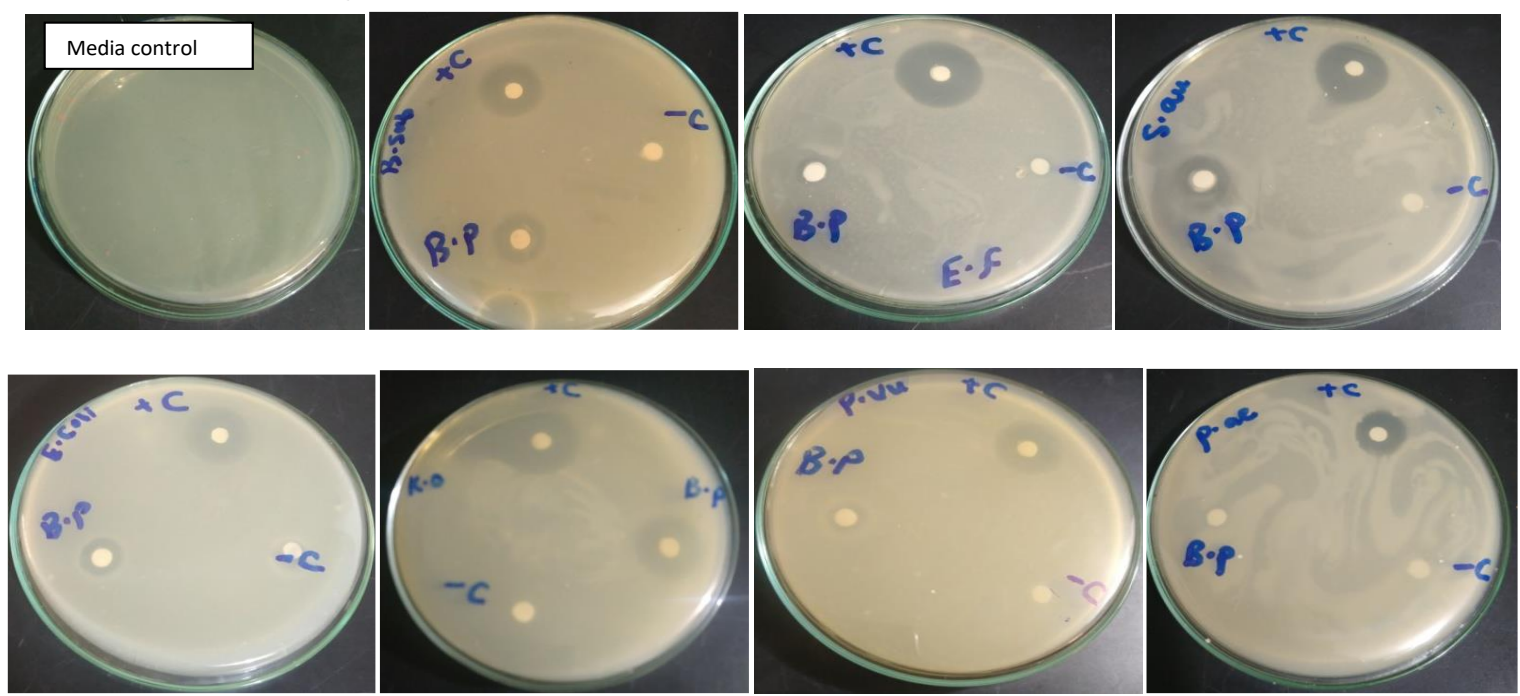

Figure 1. Antibacterial activity of black pepper aqueous seed extract. "*Where $+\mathrm{C}=\mathrm{Ciprofloxacin} ;-\mathrm{C}=\mathrm{Negative}$ control (Distilled water) and B.p = Black pepper".

Table 2. Effect of black pepper aqueous seed extract against some food pathogenic fungal strains:

\begin{tabular}{|c|c|r|r|}
\hline \multirow{2}{*}{ Fungal strain } & \multicolumn{3}{|c|}{ Zone inhibition of fungal mycelial \% } \\
\hline & $100 \mu \mathrm{l}$ & $250 \mu \mathrm{I}$ & $500 \mu \mathrm{l}$ \\
\hline Penicillium citrinum & $70.0 \pm 0.15$ & $87.0 \pm 0.40$ & $100 \pm 0.00$ \\
\hline Aspergillus niger & $39.0 \pm 0.40$ & $58.0 \pm 0.51$ & $70.2 \pm 0.30$ \\
\hline Aspergillus flavus & $11.6 \pm 0.37$ & $25.4 \pm 0.23$ & $45 \pm 0.45$ \\
\hline Fusarium oxisporum & $8.25 \pm 67$ & $19.3 \pm 0.65$ & $29.5 \pm 0.36$ \\
\hline
\end{tabular}

\subsection{Assessment of antiviral activity of black pepper aqueous seed extract:}

The results indicated that the MNTC for black pepper aqueous seed extract was $2500 \mu \mathrm{g} / \mathrm{ml}$. Fascinatingly, the antiviral activity of black pepper aqueous seed extract was explored against Herpes growth while showed some activity against Aspergillus flavus and Fusarium oxisporum. 
black pepper aqueous seed extract applies (57.26 and $13.41 \%$ ) inhibition of plaque of HSV1 and COXB4 respectively at concentration $(250 \mu \mathrm{g} / \mathrm{ml})$. The anti-herpes simplex virus might be due to the binding of phytochemical compounds in black pepper extract with the protein coat of the virus and hold the absorption of a virus into the Vero cells.

Table 3. Percentages of anti-viral effect of black pepper aqueous seed extract against HSVI.

\begin{tabular}{|c|c|c|c|c|c|c|c|c|c|}
\hline \multirow{2}{*}{ Test } & $\begin{array}{c}\text { Concentration } \\
(\mu \mathrm{g} / \mathrm{ml})\end{array}$ & \multicolumn{3}{|c|}{ O.D. } & $\begin{array}{c}\text { Mean } \\
\text { O.D. }\end{array}$ & Viability & Toxicity & $\begin{array}{c}\text { Viral } \\
\text { activity } \\
\%\end{array}$ & $\begin{array}{c}\text { Anti-viral } \\
\text { effect } \%\end{array}$ \\
\hline $\begin{array}{c}\text { Control Vero } \\
\text { cell }\end{array}$ & & 0.356 & 0.362 & 0.347 & 0.355 & 100 & 0 & & - \\
\hline HSVI & & 0.123 & 0.134 & 0.106 & 0.121 & 34.08451 & 65.91 & 100 & 0 \\
\hline \multirow{3}{*}{ Black pepper } & 250 & 0.253 & 0.264 & 0.248 & 0.255 & 71.83099 & 28.16 & 42.7350 & $\mathbf{5 7 . 2 6 5 3}$ \\
\cline { 2 - 11 } & 125 & 0.152 & 0.149 & 0.151 & 0.1506 & 42.44131 & 57.55 & 87.3219 & 12.6784 \\
\hline
\end{tabular}

Table 4. Percentages of anti-viral effect of black pepper aqueous seed extract against COXB4.

\begin{tabular}{|c|c|c|c|c|c|c|c|c|c|}
\hline \multirow{2}{*}{ Test } & $\begin{array}{c}\text { Concentration } \\
(\mu \mathrm{g} / \mathrm{ml})\end{array}$ & \multicolumn{3}{|c|}{ O.D. } & $\begin{array}{c}\text { Mean } \\
\text { O.D. }\end{array}$ & Viability & Toxicity & $\begin{array}{c}\text { Viral } \\
\text { activity } \\
\%\end{array}$ & $\begin{array}{c}\text { Anti- } \\
\text { viral } \\
\text { effect } \\
\%\end{array}$ \\
\hline $\begin{array}{c}\text { Control Vero } \\
\text { cell }\end{array}$ & & 0.356 & 0.362 & 0.347 & 0.355 & 100 & 0 & & - \\
\hline COXB4 & & 0.103 & 0.114 & 0.116 & 0.111 & 31.26761 & 68.7324 & 100 & 0 \\
\hline \multirow{2}{*}{ Black pepper } & 250 & 0.132 & 0.115 & 0.111 & 0.1193 & 33.61502 & 66.385 & 86.59 & $\mathbf{1 3 . 4 1 6}$ \\
\cline { 2 - 11 } & 62.5 & 0.113 & 0.105 & 0.121 & 0.113 & 31.83099 & 68.169 & 98.18 & 1.8197 \\
\hline
\end{tabular}
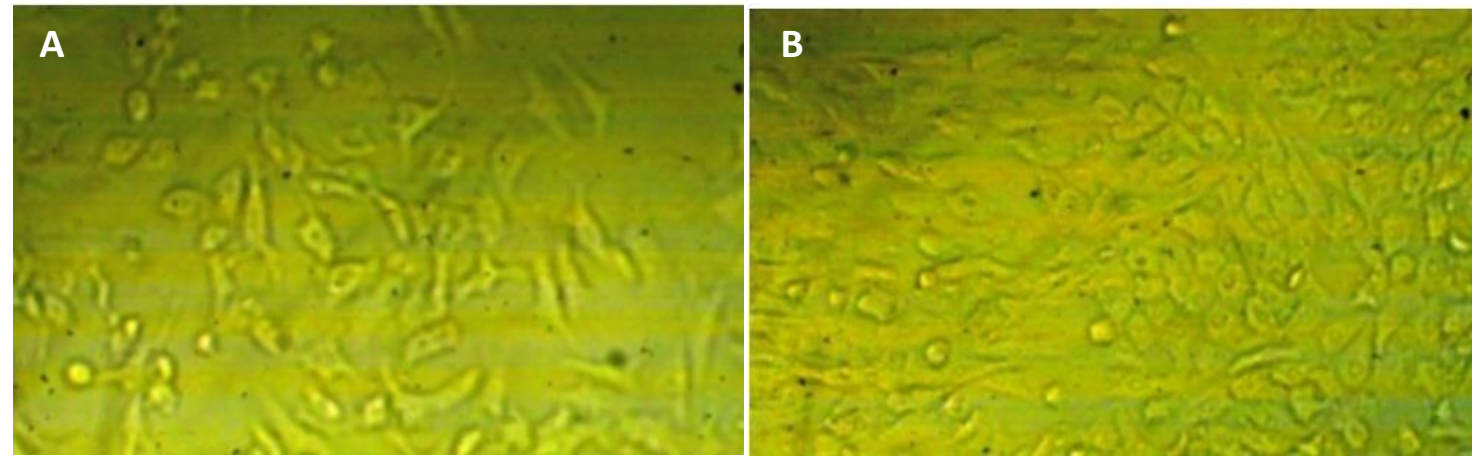

Figure 2. (A and B): Anti-viral effect of black pepper aqueous seed extract against (A): Herpes simplex viruses (HSV1) and (B): Coxsackie virus (COXB4). 
These results were definite by structural changes in the Vero cell which appeared as irregular out line and showing cytoplasmic projections, cytoplasmic vasculation, nuclear membrane begins to fragment, a number of nuclei are intricate to be seen, the cytoplasm appears as mottled, lamps diffuse mass dispersed all over the cytosol with dense lysosomes and myelin figure (3A and B). Amusingly, black pepper aqueous seed extract demonstrated antiretroviral activity and it could be used as a hopeful candidate for new and potent antiviral herbal preparation with fewer side effects.

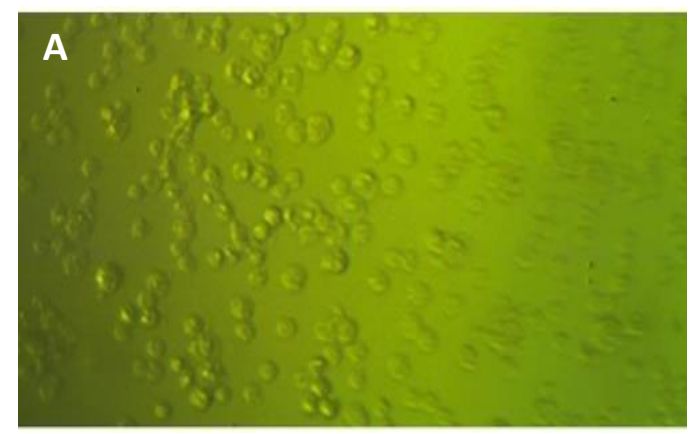

\subsection{Determination of antioxidant activity and total phenolic contents:}

The antioxidant potential of black pepper aqueous seed extract was evaluated by DPPH scavenging activity. The extract under study showed good antioxidant activity under these experimental conditions with IC50 $=155 \mu \mathrm{g} / \mathrm{ml}$.

As shown in fig. (4), DPPH activity of the measures considerably increased with increasing extract concentration. On the other hand, the results from the present study showed that the total phenolic content of black pepper aqueous seed extract was (194.05 mg GA/g extract)

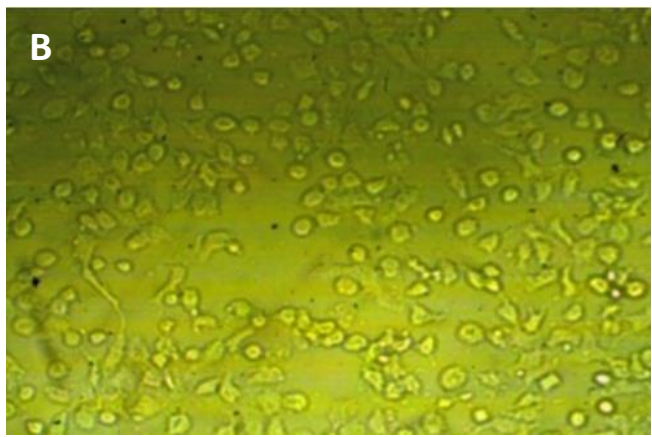

Figure 3. (3A and B): Effect of (A): Herpes simplex viruses (HSV1) and (B): Coxsackie virus (COXB4) on Vero cell.

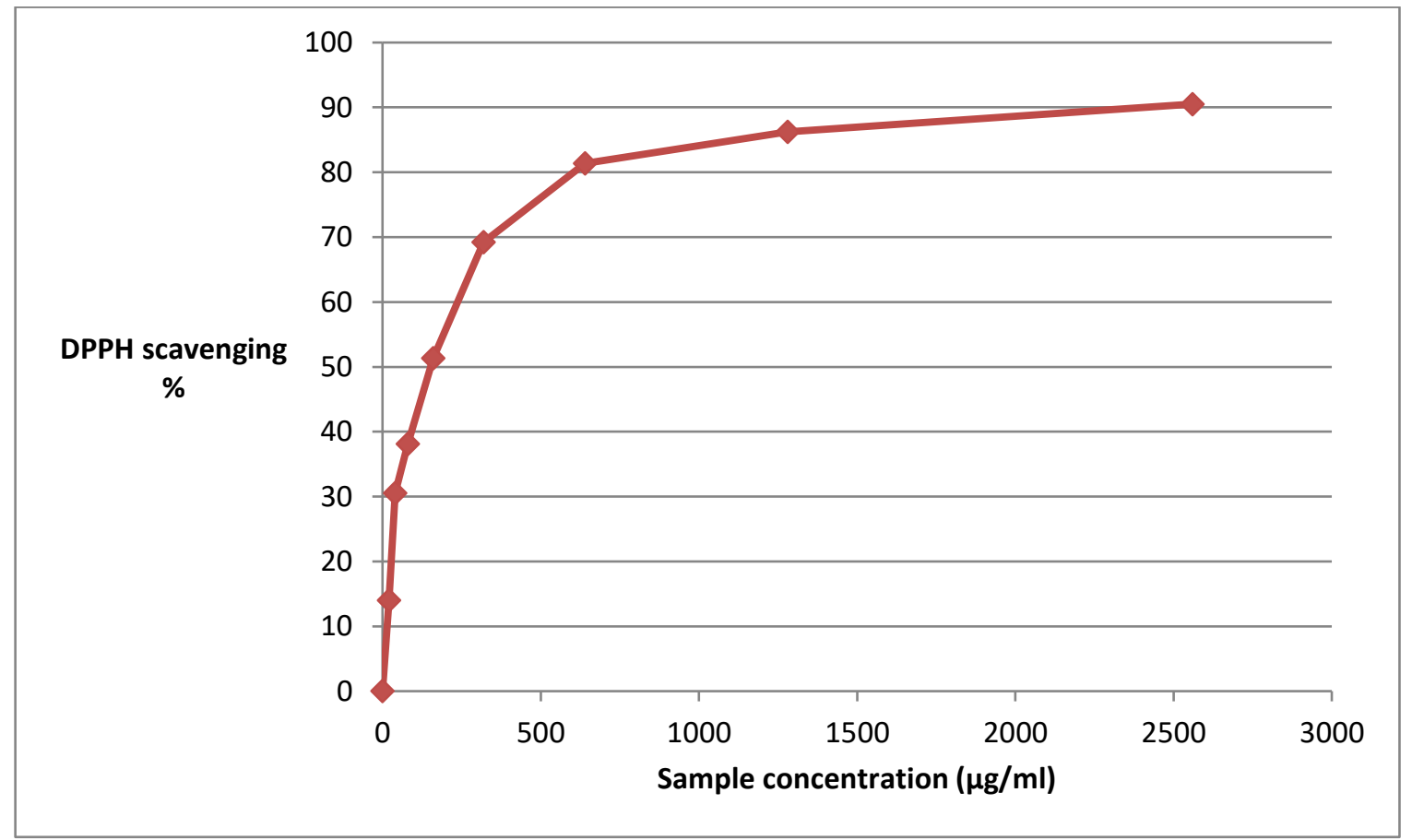

Figure 4. Evaluation of antioxidant activity by DPPH scavenging. 


\section{DISCUSSION}

A number of spices have antimicrobial activities against the food spoilage pathogenic bacteria and fungi, and some have antioxidant properties that avert the rancidity and by this means increase the shelf life of foods. This study showed superior activity of black pepper aqueous seed extract against tested Gram positive and Gram-negative bacteria. In this concern [21] indicated that the antimicrobial action of plant extracts was dependent on the composition of bacterial cell wall. Studies conducted by [22], [23], [24] declared the activity of black pepper to restrict the growth of some pathogenic bacteria. [25] mentioned that piperine of black pepper seed has antimicrobial potency. In view of the finding of other investigators, these results were agreed with [26] who reported that aqueous extract of black pepper exerted strong antibacterial potency against diverse bacterial strains isolated from oral cavity of two hundred person volunteers. The planned method of extraction donates accurate, fast, and sensitive method requiring a lesser amount of solvent to use is an active composite against pathogenic bacteria [27]. Moreover, [18] stated that black pepper ethanol extract showed antimicrobial activity against all tested bacterial strains.

In the view of the present study, the aqueous seed extract of black pepper exert complete inhibition (100\%) of Penicillium citrinum mycelium at $500 \mu \mathrm{l}$ concentration and also more effectual in controlling the mycelial growth of Aspergillus niger while showed low activity against the mycelial growth of Aspergillus flavus and Fusarium oxisporum. These results were agreed with [28] who reported the potency of both oil and extract of $P$. nigrum against diverse food pathogenic fungi using inverted petri plate technique. A study conducted by [18] reported that ethanol extract of black pepper had antifungal activity against four tested fungi and showed maximum antifungal activity towards Fusarium oxisporum. The antifungal compounds found in the plant extracts at lower concentrations were found to be fungistatic while become fungicidal at higher concentrations as reported by [29]. This fungicidal outcome of many spices may possibly as a cause of cell wall lysis and cytoplasmic membrane of fungal species as a result of liberation of antimicrobial products and also the plant lytic enzymes found in spices act on the fungal cell wall leading to breakdown of B-1,3 and 1,6 glycan and chitin polymer [30].

In the present investigation, data revealed that black pepper aqueous seed extract applies (57.26 and $13.41 \%$ ) inhibition of plaque of HSV1 and COXB4 respectively at concentration $(250 \mu \mathrm{g} / \mathrm{ml})$. These results were virtually in accordance with [31] who noted the potency of $P$. nigrum extract to inhibit Coxsackie virus type B3 (CVB3) and the $\mathrm{IC}_{50}$ was $10.6 \mu \mathrm{g} / \mathrm{mL}$ through assay of a cytopathic consequence inhibition. On the other hand, [14] reported that the Piper nigrum chloroform extract exerted higher activity than methanolic extract against Vesicular stomatitis Indiana virus and Human para influenza virus on HeLa cell line. HSV infect more than 4 billion people over the world, accounting a large saddle of disease that can be noticeable as ulcerations of oral and genital, neonatal disease and herpetic keratitis [32], [33]. Coxsackie viruses belong to the genus of Enterovirus and family Picornaviridae. Enteroviruses are the most common and significant pathogens of human and frequently occur in both adults and children [34], [35]. It named as Hand, foot, mouth Disease (HFMD) because it causes blister-like rash involving the hands, foot and mouth. Also, it causes diseases of muscles, lungs and 
heart [36]. Black pepper has antiviral action which supports the immune system, increase body's natural defenses against some diseases like colds, mumps, measles etc.

In the current study black pepper aqueous seed extract showed good antioxidant activity with IC50 $=155 \mu \mathrm{g} / \mathrm{ml}$ and total phenolic content was (194.05 $\mathrm{mg} \mathrm{GA} / \mathrm{g}$ extract). Several plants naturally generate secondary metabolites such as flavonoids and polyphenol which operate as antioxidants [37], [38]. [39] stated that, many plant extracts have the ability to scavenge DPPH radicals in vitro. It is well recognized that phenolic compounds belong to the bioactive compounds of plant and have superior health-promoting activities [40]. The phenolic content of several plants and plant extracts takes extensive interest because of its prospective for antioxidant activity. Phenolic compounds act as antioxidants due to their facility to give a hydrogen atom on the road to make constant radical intermediates. [41] assessed the total phenolic content and antioxidant activity of Piper nigrum L. and recorded that total phenolic content was $338 \pm 1.414 \mathrm{mg} \mathrm{GA} / \mathrm{g}$ and antioxidant activity was 13.28 .

\section{CONCLUSION}

Summarizing these outcomes, it can be fulfilled that black pepper aqueous seed extract possesses antibacterial, antifungal, antioxidant and anti-viral activity against HSV1 and COXB4 viruses. In future, more studies must be conducted in this regard to examine the possibility of using black pepper medically in some anti-microbial drugs.

\section{References}

1. Voravuthikunchai, S.; Lortheeranuwat, A.; Jeeju, W.; Sririrak, T.; Phongpaichit, S. and Supawita, T. (2004): Effective medicinal plants against enterohaemorrhagic Escherichia coliO157:H7. J. Ethnopharmacol.,94: 4954.

2 .Mothana, R.A. and Lindequist, U. (2005): Antimicrobial activity of some medicinal plants of the island Soqotra. J.Ethnopharmacol., 96: 177-181.

3 .Agunu, A.; Yusuf, S.; Andrew, G.O.; Zezi, A.U. and Abdurahman, E.M. (2005): Evaluation of five medicinal plants used in diarrhea treatment in Nigeria. J.Ethnopharmacol., 101: 27-30.

4 .Buwa, L.V. and Van Staden, J. (2006): Antibacterial and antifungal activity of traditional medicinal plants used against venereal diseases in South Africa. J.Ethnopharmacol., 103: 139-142.

5 .Mata, A.T.; Proenca, C.; Ferreira A.R.; Serralheiro, M.L.M.; Nogueira, J.M.F. and Araujo, M.E.M. (2007): Antioxidant and anti-acetylcholinesterase activities of five plants used as Portuguese food species. Food Chem., 103: 778-786.

6 .Park, J.B. (2011): Identification and quantification of a major antioxidant and anti-inflammatory phenolic compound found in basil, lemon thyme, mint, oregano, rosemary, sage, and thyme. Int. J. Food Sci. Nutr., 62: 577-584 .

7 .Srinivasan, K. (2007): Black pepper and its pungent principle-piperine. A review of diverse physiological effects. Crit. Rev. Food Sci. Nutr., 47: 735-748 . 
8 .Zengin, H. and Baysal, A.H. (2014): Antibacterial and antioxidant activity of essential oil terpenes against pathogenic and spoilage-forming bacteria and cell structure-activity relationships evaluated by SEM microscopy. Molecules, 191777317798 .

9 .Lv, F.; Liang, H.; Yuan, Q. and Li, C. (2011): In vitro antimicrobial effects and mechanism of action of selected plant essential oil combinations against four food-related microorganisms. Food Res. Int., 44: 3057-3064 .

10 .Bajpai, V.K.; Al-Reza, S.M.; Choi, U.K.; Lee, J.H. and Kang, S.C. (2009): composition, antibacterial and antioxidant activities of leaf essential oil and extracts of Metasequoia glyptostroboides Miki ex Hu. Food Chem. Toxicol., 47: 1876-1883.

11 .Bandoniene, D.; Venskutonis, P.R. and Murkovic, M. (2002): Antioxidant activity of Sage (Salvia offcinalis L.), Savory (Saturejahortensis L.) and Borage (Borago officinalis L.) extracts in rapeseed oil. Eur. J. Lipid Sci. Technol., 104:286-292.

12 .Ozcan, M. and Erkmen, O. (2001): Antimicrobial activity of the essential oils of Turkish plant spices. Eur. Food Res. Tech., 212:658-660.

13 .Vardar-unlu,G.; Candan, F.; Sokmen, A.; Daferera, D.; Polissiou, M.; Sokmen,M.; Donmez, E. and Tepe, B. (2003): Antimicrobial and antioxidant activity of the essential oil and methnol extracts of Thymus pectinatus Fisch. Et Mey. Var. pectinatus (Lamiaceae), J. Agric. Food Chem., 51(1):63-7.

14 .Priya, N.C. and Saravana, P.K. (2017): Antiviral Activities and Cytotoxicity Assay of Seed Extracts of Piper longum and Piper nigrum on Human Cell Lines Int. J. Pharm.
Sci. Rev. Res., 44(1), Article No. 42: 197202.

15 .Meghwal, M. and Goshwami, T. (2012): Chemical composition, nutritional, medicinal and functional properties of black pepper: Sci Rep., 1:1 -5.

16 .Halliwell, B. (2007): Biochemistry of Oxidative Stress Bioche- chemical Society Transactions, 35: 1147-1150.

17 .Yadav, A.: Yadav, A.; Kumari, R.: Mishra, J.P.: Srivatva, S. and Prabha, S. (2016): Antioxidants and its functions in human body -Res. Environ. Life Sci., 9(11): 1328-1331.

18 .Shiva Rani, S.K.; Neeti Saxena, and Udaysree, (2013): Antimicrobial Activity of Black Pepper (Piper nigrum L.) Global J. of Pharmacol., 7(1): 87-90, DOI: 10.5829/idosi.gjp.2013.7.1.1104.

19 .Anesini, C.; Ferraro, E.G. and Filip, R. (2008): Total Polyphenol Content anAntioxidant Capacity of Commercially Available Tea (Camellia sinensis) inArgentina J. Agric. Food Chem., 56: 9225-9229.

20 .Singleton, V.L. and Rossi, J.A., (1965): Colorimetry of total phenolics with phosphomolybdic-phospho-tungstic acid reagents. Am. J. Enol. Vitic., 16: 144158.CAS, Google Scholar.

21 .Shrivastava, S.; Bera, T.; Roy, A.; Singh, G.; Ramachandrarao, P. and Dash, D. (2007): Characterization of enhanced antibacterial effects of novel silver nanoparticles. Acs. Nano., 3: 1357-64.

22 .Zhang, J.; Ye, K.P.; Zhang, X.; Pan, D.; Sun, Y. and Cao, J.X. (2017): Antibacterial Activity and Mechanism of Action of Black Pepper Essential Oil on Meat-Borne 
Escherichia coli, Frontiers in Microbiologywww.frontiersin.org DOI: 10.3389/fmicb.2016.02094.

23 .Yohannes, A.; Eyalarasan, K.; Eyob, L.; Yemane, A.; Ghebrengus, E.; Weldemariam, L. and Yohannes. T. (2018): Antibacterial and Antifungal Activities of easily grown Eritrean Black PepperInter. J. of Eng. Res.\& Tech. (IJERT) http://www.ijert.org ISSN: 2278-0181 IJERTV7IS020028 Vol. 7 Issue 02, 2018.

24 .Takooree, H.; Aumeeruddy, M.Z.; Kannan, R.R.; Rengasamy, Venugopala, N.K.; Jeewon, R. and Zengin, G. (2019): A systematic review on black pepper (Piper nigrum L.): from folk uses to pharmacological applications Critical Reviews in Food Science and Nutrition Volume 59, 2019 - Issue sup1: 3rdInternational Symposium on Phytochemicals in Medicine and Food.

25 .Agrawal, R. and Patwardhan, M.V. (1994): Formation of piperine from in vitroculture of Piper nigrum L. Indian J. of Plant Phys., 37(3):171-173 .

26 .Khan, M. and Siddiqui, M. (2007): Antimicrobial activity of Piper fruits. Nat. prod. Rad., 6:111-113.

27 .Kaho, Z.M.; Kadum, A.R. and Hadi, A.A. (2019): Evaluation of Antibacterial Activity of Piper nigrum Extract against Streptococcus mutans and Escherichia coli, /J. Pharm. Sci. \& Res., 11(2): 367-370.

28 .Singh, G.; Marimuthu, P.; Catalan, C. and deLampasona, M.P. (2004): Chemical, antioxidant and antifungal activities of volatile oil of black pepper andits acetone extract. J. Sci. Food Agric., 84:1878-1884. DOI: $10.1002 /$ jsfa. 1863.

29 .Banso, A.;Adeyoemo, S.O. and Jeremiah, P.(1999): Antimicrobial properties ofVernonia amygdalinaaxtract. J. Appl. Sci. and Manag., 3: 9-11.

30 .Brull, S. and Coote,P. (1999):Preservative agents in foods. Mode of action andmicrobial resistance mechanisms. Int. J. Food Microbiol., 501517.

31 .Mair, C.E.; Grienke, U.; Draschl, C.; Kramer, C.; Richter, M.; Grafenstein, S.; Kirchmair, J.; Liedl, K.R.; Schmidtke, M. and Rollinger, J.M. (2014): Antiviral and anti-proliferative in vitro activities of piperamides from black pepper, PlantaMed., 2016; 82(S 01): S1-S381

32 .Looker, K.J.; Magaret, A.S.; May, M.T.; Turner, K.M.E.; Vickerman, P.;Gottlieb, S.L. and Newman, L.M. (2015):Global and regional estimates ofprevalent andincident herpes simplex virus type 1 infections in 2012. PLoS One .

33 .Greninger, A.L.; Roychoudhury, P.; Xie, H.; Casto, A.; Cent, A.; Pepper, G.; Koelle, M.D.; Huang, M.L.; Wald, A.; Johnston, C. andJerome, K.R. (2018):Ultrasensitive Capture of Human Herpes Simplex Virus Genomes Directly from Clinical Samples Reveals Extraordinarily Limited Evolution in Cell CultureRESEARCH ARTICLE Clinical Science and Epidemiology 2018,https://doi.org/10.1128/MSPHERED IRECT.00283-18.

34 .Jani, S.; Shabih, S.; Petri, S.; Arun, P.P. and Robert, S. (2012): Structural analysis of coxsackievirus A7 reveals conformational changes associated withuncoating. J.Virol., 86 (13): 72077215.

35 .Afrose, T. (2017): Coxsackie VirusThe Hand, Foot, Mouth Disease JOJ Pub Health DOI: 10.19080/JOJPH.2017.01.555566. 
36 .Centers for Disease Control and Prevention, (2013): Hand, Foot, and Mouth Disease. CDC, USA

37 .Carvalho, M.; Ferreira, P.J. and Mendes, V.S. (2010): Human cancer cellantiproliferative and antioxidant activities of Juglans regia L. Food Chem. Toxicol., 48: 441-447.

38 .Shantabi, L.; Jagetia, G.C.; Ali, M.A.; Singh, T.T. and Devi, S.V. (2014): Antioxidant potential of Croton caudatus leaf extract in vitro. Transl. Med. Biotechnol., 2(6): 1-15

39 .Lalrinzuali, K.; Vabeiryureilai, M.; Jagetia, G.C. and Lalawmpuii, P.C. (2015): Free radical scavenging and antioxidant potential of different extracts of Oroxylum indicum in vitro. Adv.Biomed. Pharm., 2(3): $120-130$.

40 .Denardin, C.C.; Hirsch, G.E; da Rocha, R.F.; Vizzotto, M.; Henriques, A.T.; Moreira, J.C.F.; Guma, F.T.C.R. and Emanuelli, T. (2015): Antioxidant capacityand bioactive compounds of four Brazilian native fruits. J Food Drug Anal., 23(3):387-398 .

41. Salanţă, L.C.; Tofană, M.; Socaci, S.; Pop, C. and Pop, A. (2015): Evaluationof Polyphenol Content and Antioxidant Properties of some Fruit SeedsBulletinUASVM Food Science and Technology 72(1) / 2015 ISSN-L 23442344. 